\title{
Professional Learning Communities: Perceptions, Challenges and Possibilities in Ambo University
}

\author{
Negesse Gemechu ${ }^{1} \quad$ Fekede Tullie ${ }^{2}$ \\ Department of Teacher Education, University of Ambo,Ethiopia
}

\begin{abstract}
Recent studies suggest that professional learning community is necessary for increasing teacher's commitment to their goals and allows them to share their successful practices. The purpose of this study was to analyze the implementation of professional learning communities: perceptions, challenges and possibilities in Ambo University. The study was conducted using mixed research method and explanatory sequential mixed research design. In the first case, in order to obtain quantitative data a close ended questioner were administered to 250 teachers and analyzed with the help of descriptive statistics namely: mean score, standard deviation, percentages, $\mathrm{t}$-test. In the second case, qualitative data was obtained through semi structured interview and focused group discussion. The result of the study shows that, all the six dimensions of professional learning community were to a great extent, perceived to be unimplemented in Ambo University. Implications, which are assumed to improve the practices of professional learning community, were highly recommended in the study.
\end{abstract}

Keywords: shared leadership, shared practice, shared values and vision, supportive conditions, collective learning DOI: $10.7176 / \mathrm{JEP} / 11-34-05$

Publication date: December $31^{\text {st }} 2020$

\section{IMPLEMENTATION OF PROFESSIONAL LEARNING COMMUNITIES}

Professional Leaning Community

One of the major concerns of parents, communities and students of the present day is the decreasing standards of education. According to (Birman\& Yoon, 2001), the most important factor to improve educational quality is to increase teachers collaboration. After the extensive review of 800 meta-analysis (John \& Hattie, 2010) concluded that, one effective way to improve the quality of education is to organize teachers into collaborative teams as professional learning community. In addition, research studies conducted by (Harpaz, 2014; Bubb\&Earley, 2007; Zmuda, Kuklis, \& Kline, 2004; Heikkinen, Jokinen and Tynjälä, 2012) increasingly recognized professional learning communities as a means for profound and positive educational change and improvement.

Therefore, the main aim of professional learning community is to provide teachers with an opportunity to meet on regular basis to share and analyze their experiences so as to maximize student's achievement. According to (Fullan, 1991), professional learning community helps to reduce professional isolation of teachers and allow for sharing of successful practices and provide support. In professional learning community, teachers working together have the potential to raise morale and enthusiasm (Lee, Smith, \& Croninger, 1995). This professional learning community may also increase the likelihood of experimentation among teachers (Rosenholtz, 1989). Despite the overwhelming evidence of the benefits of a collaborative culture, the tradition of teacher isolation continues to pose a challenging barrier to those hoping to implement professional learning community concepts in their schools (DuFour, Eaker, \& DuFour, 2005).

As the result, professional learning community is now a crucial concept in many current studies of education improvement as a way of building up an institution's capacity for development. In this regard, (Stoll, Bolam, McMahon, Wallace and Thomas, 2006) have noted that the formation of professional learning communities hold great promise for capacity building and sustainable educational improvement. Researchers in many fields have come to similar conclusions concerning organizational development and offer similar models (Du Four\&Eaker, 1998).

Hence, the primary goal of any educational institution is to ensure learning for all students. The most promising strategy for fulfilling that goal is to develop the staff's capacity to function as a professional learning community (PLC), a tool by which schools and teachers can continue to grow professionally. At the back of this rationale, in our context, a university wide professional learning community initiative was started with the intention to build capacity for learning, and ultimately improve educational practices and enhance students learning. The aim of the initiative was to provide teachers an opportunity to meet on weekly basis, in their own time to share and analyze experiences, ideas and new practices. For us, a professional learning community comprises groups of new and experienced teachers, who collectively examine and improve their own professional practices and enhance students learning. Despite the attention given to professional learning community as a means to enhance learning for all, our experience as insiders and participants, show that the initiative is not up to its premises. Hence, this study is intended to investigate about professional learning communities: perceptions, challenges and possibilities in Ambo university and mentioned the following objectives:

* To explore the extent to which the dimensions of a professional learning community was evidenced in 
Ambo University.

* To identify how teachers view professional learning communities.

* To identify teachers perception as enablers or challenges in initiating and developing an effective

Professional learning community.

\section{Methods}

Participant

The total population of the study was 700 teachers. Using (Yamane, 1967) formula for calculating sample size by considering a $95 \%$ confidence level and $p=0.5$, from the total population of 700 teachers 250 of which, $(n=242)$ men and $(n=8)$ women were selected. Accordingly, participants consisted of Natural science college $(n=38)$, Education and behavioral science college $(n=13)$, Agriculture college $(n=38)$, Technology college $(n=37)$, Cooperative $(n=12)$, Law college $(n=8)$, Social science college $(n=45)$, FB (waliso) $(n=32)$ and Health College $(n=27)$.

Materials

In order to provide an answer for the research questions respondents were asked to rate the level of professional learning community implementation indicator that was developed by (Hannaford, 2010). Accordingly, respondents were asked to rate a 48 different professional learning community indicator items that involve a scale of $1-5$. Where $1=$ strongly disagree, $2=$ disagree $3=$ undecided $4=$ agree, and $5=$ strongly agree. The mean score of each of the sample for the forty eight indicator was compared with the mean score $(M=3.0)$.

Furthermore, the 48 indicator items were grouped into six categories based on the Hannaford (2010) model of professional learning community. The total scores for each category were calculated by summing responses for the three related indicator items. A one-sample t-test, comparing each total categorical mean score to the mean score $(M=3)$ from a hypothetical categorical normal distribution was conducted for each of the six categories.

Procedures

Primarily, for quantitative part participants was selected using stratified sampling method in order to select participants proportionally from all college. Next, from each college samples were selected with simple random sampling in order to provide equal chances for all participants. Lastly, those teachers who were assumed to better understand the issue under investigation were selected using purposive sampling method for interview and focus group discussion purpose.

The study was conducted using mixed research method. Mixed research method was used for the very reason that, the study involves the usage of questioner developed by (Hord, 2010) as the survey instrument and was administered to the selected teachers to obtain quantitative data. Once the data was collected, it was analyzed using quantitative method with the help of descriptive statistics namely: mean score, standard deviation, percentages, $t$ test (for variables with two groups). In order to make the analysis of data easier SPSS version 23 was used.

Similarly, qualitative data that was obtained through focused group discussion and interview was analyzed with the help of qualitative data analysis method. An explanatory sequential mixed design was utilized in the study in that, researchers were first gathered quantitative data and based on the quantitative data, interviews and focused group discussion were developed.

\section{Results}

An analysis of respondent mean scores for each of the 48 indicator items developed by (Hannaford, 2010) for the level of implementation revealed only four items $4(8.4 \%)$ had mean score greater than 3.00 indicating that they were implemented by the university. These items includes: "Staff members informally share ideas and suggestions for improving student learning" $(M=3.36, S D=1.207)$; "Shared values support norms of behavior that guide decisions about teaching and learning" $(\mathrm{M}=3.15, \mathrm{SD}=1.16)$; "Communication systems promote a flow of information among staff members" $(M=3.05, S D=1.49)$; "Staff members share visions for institute/college/school improvement that have an undeviating focus on student learning" $(M=3.03, S D=1.23)$. The majority of indicators $42(87.5 \%)$ received mean value less than 3.00 indicating that they were perceived to be unimplemented by the university.

In addition, when compared to the mean score $(M=3.0)$ from a hypothetical normal distribution, one-sample t-test results indicated the differences between the normal distribution and sample mean scores for all of the 48 indicator items were statistically significant at $p<.05$.

\section{Findings in terms of the six dimensions of professional Learning Community}

Analysis of teachers perception reveal that, the implementation of supportive condition- structure $(M=2.92$, $S D=1.30)$ and shared values and vision $(M=2.92, S D=1.14)$ as dimension of professional learning community ranked at the first level whereas, shared and supportive leadership appeared at the last stage $(M=2.74, \mathrm{SD}=1.26)$.

When the six dimensions of professional learning community compared to the mean score $(M=3.0)$ from a hypothetical normal distribution, one-sample t-test results indicated the differences between the normal 
distribution and sample mean scores for all of the 6 indicator items were statistically significant at $p<.05$

Table1.level of implementation of professional learning communities by categories as perceived by teachers

\begin{tabular}{|c|c|c|c|}
\hline Item & M & SD & $\mathrm{T}$ \\
\hline 1.Shared and supportive leadership (Mean of item & 2.74 & 1.26 & 34.14 \\
\hline 2.Shared values and Vision (Mean of items 11-18 & 2.92 & 1.14 & 40.3 \\
\hline 3.Collective learning and application(Mean of item 19-29) & 2.83 & 1.17 & 7.87 \\
\hline 4. Shared personal practice. Mean of item $30-36$ & 2.91 & 1.17 & 39.25 \\
\hline 5.Supportive conditions- relationship Mean of items 37-40 & 2.86 & 1.14 & 39.57 \\
\hline 6. Supportive condition-Structure. Mean of items 41-48 & 2.92 & 1.3 & 35.57 \\
\hline
\end{tabular}

Comparison $M=3.0 * p=<0.05 N=249: 1=$ strongly disagree, $2=$ disagree $3=$ undecided $4=$ agree, and $5=$ strongly agree

\section{Dimension 1: Shared and Supportive Leadership}

The mean of all items (1-10) indicated respondent's disagreement with the implementation of shared and supportive leadership $(M=2.74, S D=1.26)$. Means for item5- opportunities are provided for staff members to initiate change $(M=2.87, S D=1.27)$ received the maximum mean value whereas, mean for item 6 - leadership is proactive and addresses areas where support is needed $(M=2.63, S D=1.26)$ received the minimum value in terms of their implementation.

Based on (Hill, 2007) levels of classification, since only $33 \%$ of teachers showed a positive response for shared and supportive leadership the university was said to found at the non-demonstration stage in the implementation of this dimension.

Table2-Results of professional learning community Survey Instrument - Shared and Supportive Leadership

\begin{tabular}{|c|c|c|c|c|c|c|c|c|}
\hline \multirow{2}{*}{ Item } & \multirow{2}{*}{ Mean } & \multirow{2}{*}{ SD } & \multicolumn{2}{|c|}{$\% \mathrm{D}$} & \multicolumn{2}{|c|}{$\% \mathrm{~A}$} & \multicolumn{2}{|c|}{$\%$ UD } \\
\hline & & & $\mathrm{F}$ & $\%$ & $\mathrm{~F}$ & $\%$ & $\mathrm{~F}$ & $\%$ \\
\hline $\begin{array}{l}\text { 1. Staff members are consistently involved in discussing } \\
\text { and making decisions about most issues. }\end{array}$ & 2.79 & 1.322 & 125 & 50.2 & 97 & 38.9 & 27 & 10.8 \\
\hline $\begin{array}{l}\text { 2. The leadership incorporates advice from staff } \\
\text { members to make decisions. }\end{array}$ & 2.72 & 1.251 & 119 & 47.8 & 79 & 31.7 & 51 & 20.5 \\
\hline 3. Staff members have accessibility to key information. & 2.77 & 1.292 & 127 & 51 & 93 & 37.3 & 29 & 11.6 \\
\hline $\begin{array}{l}\text { 4. The leadership is proactive and addresses areas where } \\
\text { support is needed. }\end{array}$ & 2.63 & 1.266 & 135 & 54.2 & 74 & 29.7 & 40 & 16.1 \\
\hline $\begin{array}{l}\text { 5. Opportunities are provided for staff members to } \\
\text { initiate change. }\end{array}$ & 2.87 & 1.274 & 116 & 46.6 & 90 & 36.1 & 43 & 17.3 \\
\hline $\begin{array}{l}\text { 6. The leadership shares responsibility and rewards for } \\
\text { innovative actions. }\end{array}$ & 2.67 & 1.303 & 124 & 49.8 & 76 & 30.5 & 49 & 19.7 \\
\hline $\begin{array}{l}\text { 7. The leadership participates democratically with staff } \\
\text { sharing power and authority. }\end{array}$ & 2.64 & 1.316 & 134 & 60.8 & 75 & 30.1 & 40 & 16.1 \\
\hline $\begin{array}{l}\text { 8. Leadership is promoted and nurtured among staff } \\
\text { members. }\end{array}$ & 2.75 & 1.189 & 121 & 48.6 & 80 & 32.1 & 48 & 19.3 \\
\hline 9.Decision-making takes place through committees & 2.81 & 1.262 & 117 & 47 & 83 & 33.3 & 49 & 19.7 \\
\hline $\begin{array}{l}\text { 10.Staff members use multiple sources of data to make } \\
\text { decisions about teaching and learning }\end{array}$ & 2.77 & 1.211 & 117 & 47 & 83 & 33.3 & 49 & 19.5 \\
\hline Total Mean & 2.74 & 1.26 & 123 & 50.3 & 83 & 33.3 & 43 & 17.1 \\
\hline
\end{tabular}

*M mean, SD Standard deviation, $\mathrm{D}=$ Disagree, $\mathrm{A}=$ Agree, $\mathrm{UD}=$ undecided

\section{Dimension 2: Shared Values and Vision}

Means for almost all items indicated respondent's disagreement with the implementation of shared and supportive leadership ( $M=2.9, S D=1.1)$. Only means for two items: item 12- shared values that support norms of behavior that guide decisions about teaching $(M=3.15, S D=1.16)$ and item 13- staff members share visions for institute/college/school improvement that have an undeviating focus on student learning $(M=3.03, S D=1.23)$ received an agreed response and maximum mean value from this dimension. Item 11- a collaborative process exists for developing a shared sense of values among staff' $(M=2.74, S D=1.9)$ on the other hand received the minimum mean value. As $37.4 \%$ of respondents revealed a positive response for shared values and vision, the result according to (Hill, 2007) places the university at the non-demonstration of the implementation of a professional learning community in relation to this dimension. 
Table3. Results of professional learning community Survey Instrument-Shared values and vision.

\begin{tabular}{|c|c|c|c|c|c|c|c|c|c|}
\hline & \multirow{2}{*}{ Item } & \multirow{2}{*}{ M } & \multirow{2}{*}{ SD } & \multicolumn{2}{|l|}{$\% \mathrm{D}$} & \multicolumn{2}{|l|}{$\% \mathrm{~A}$} & \multicolumn{2}{|c|}{$\%$ UD } \\
\hline & & & & F & $\%$ & $\mathrm{~F}$ & $\%$ & F & $\%$ \\
\hline 11 & $\begin{array}{l}\text { A collaborative process exists for developing a } \\
\text { shared sense of values among staff. }\end{array}$ & 2.74 & 1.09 & 120 & 48.1 & 75 & 30.1 & 54 & 21.7 \\
\hline 12 & $\begin{array}{l}\text { Shared values support norms of behavior that } \\
\text { guide decisions about teaching and learning. }\end{array}$ & 3.15 & 1.16 & 79 & 31.7 & 118 & 47.4 & 52 & 20.9 \\
\hline & Staff members share visions for & & & & & & & & \\
\hline 13 & $\begin{array}{l}\text { institute/college/school improvement that have } \\
\text { an undeviating focus on student learning. }\end{array}$ & 3.03 & 1.23 & 96 & 38.6 & 108 & 43.3 & 45 & 18.1 \\
\hline 14 & $\begin{array}{l}\text { Decisions are made in alignment with the } \\
\text { school's values and vision. }\end{array}$ & 2.9 & 1.13 & 105 & 42.1 & 87 & 34.9 & 57 & 22.9 \\
\hline 15 & $\begin{array}{l}\text { A collaborative process exists for developing a } \\
\text { shared vision among staff. }\end{array}$ & 2.92 & 1.09 & 99 & 39.7 & 94 & 37.7 & 56 & 22.5 \\
\hline 16 & $\begin{array}{l}\text { University goals focus on student learning } \\
\text { beyond test scores and grades. }\end{array}$ & 2.81 & 1.24 & 110 & 44.2 & 90 & 36.1 & 49 & 19.7 \\
\hline 17 & $\begin{array}{l}\text { Policies and programs are aligned to the } \\
\text { University's vision. }\end{array}$ & 2.99 & 1.11 & 85 & 34.1 & 95 & 38.1 & 69 & 27.7 \\
\hline \multirow[t]{3}{*}{18} & $\begin{array}{l}\text { Data are used to prioritize actions to reach a } \\
\text { shared vision. }\end{array}$ & 2.86 & 1.08 & 99 & 39.7 & 79 & 31.7 & 71 & 28.5 \\
\hline & Total & 23.4 & 9.2 & 793 & 318.2 & 746 & 299.3 & 453 & 182 \\
\hline & mean & 2.9 & 1.1 & 99 & 39.8 & 93 & 37.4 & 57 & 22.75 \\
\hline
\end{tabular}

*M mean, SD Standard deviation, $\mathrm{D}=$ Disagree, $\mathrm{A}=$ Agree, $\mathrm{UD}=$ undecided

\section{Collective Learning and Application}

Based on the results obtained from analyzed data the average rating, for each item 19 through 29 ranged from 2.71 to 3.00 and showed there was almost disagreement among the respondents that elements of collective learning and application is evident in the university $(M=2.83, S D=1.17$ and based to (Hill, 2007) levels of classification this dimension is found at the non-demonstration level since only $29.62 \%$ of the teachers surveyed indicated a positive response for the dimension. Item 29 - staff members collaboratively analyze student work to improve teaching and learning" $(M=2.97, S D=1.21)$ received the maximum mean value and item 26 - staff members learn together and apply new knowledge to solve problems $(M=2.71, S D=1.13)$ receives the minimum mean value in terms of its implementation.

Table4-Results of professional learning community Survey Instrument-Collective Learning and Application.

\begin{tabular}{|c|c|c|c|c|c|c|c|c|}
\hline \multirow[t]{2}{*}{ Item } & \multirow[t]{2}{*}{$\mathrm{M}$} & \multirow[t]{2}{*}{ SD } & \multicolumn{2}{|l|}{$\% \mathrm{D}$} & \multicolumn{2}{|c|}{$\% \mathrm{~A}$} & \multirow{2}{*}{$\begin{array}{l}\text { UD } \\
F\end{array}$} & \multirow[b]{2}{*}{$\%$} \\
\hline & & & $\mathrm{F}$ & $\%$ & $\mathrm{~F}$ & $\%$ & & \\
\hline $\begin{array}{l}\text { 19.Staff members work together to seek } \\
\text { knowledge, skills and strategies }\end{array}$ & 2.71 & 1.19 & 125 & 50.2 & 73 & 29.3 & 51 & 20.5 \\
\hline $\begin{array}{l}\text { 20. Staff members apply new } \\
\text { learning/knowledge to their work. }\end{array}$ & 2.85 & 1.19 & 122 & 48.9 & 86 & 35 & 41 & 16.1 \\
\hline $\begin{array}{l}\text { 21. Collegial relationships exist among staff } \\
\text { members that reflect commitment to } \\
\text { university improvement efforts. }\end{array}$ & 2.83 & 1.12 & 115 & 46.2 & 77 & 22.9 & 57 & 30.9 \\
\hline $\begin{array}{l}\text { 22. Staff members plan and work together to } \\
\text { search for solutions to address diverse student } \\
\text { needs. }\end{array}$ & 2.9 & 1.16 & 110 & 44.17 & 85 & 34.13 & 54 & 21.7 \\
\hline $\begin{array}{l}\text { 23. A variety of opportunities and structures } \\
\text { exist for collective learning through open } \\
\text { dialogue. }\end{array}$ & 2.74 & 1.11 & 114 & 45.8 & 66 & 26.5 & 69 & 27.7 \\
\hline $\begin{array}{l}\text { 24. Staff members engage in dialogue that } \\
\text { reflects a respect for diverse ideas that lead to } \\
\text { continued inquiry. }\end{array}$ & 2.8 & 1.1 & 116 & 46.6 & 75 & 30.1 & 58 & 23.3 \\
\hline $\begin{array}{l}\text { 25. Professional development focuses on } \\
\text { teaching and learning. }\end{array}$ & 2.84 & 1.22 & 122 & 48.9 & 93 & 37.4 & 34 & 13.7 \\
\hline $\begin{array}{l}\text { 26. Staff members learn together and apply } \\
\text { new knowledge to solve problems. }\end{array}$ & 2.71 & 1.13 & 124 & 49.8 & 47 & 18.9 & 78 & 31.3 \\
\hline
\end{tabular}




\begin{tabular}{|c|c|c|c|c|c|c|c|c|}
\hline \multirow[t]{2}{*}{ Item } & \multirow[t]{2}{*}{ M } & \multirow[t]{2}{*}{$\mathrm{SD}$} & \multicolumn{2}{|l|}{$\% \mathrm{D}$} & \multicolumn{2}{|l|}{$\% \mathrm{~A}$} & \multirow{2}{*}{$\begin{array}{l}\% \\
\text { UD } \\
\mathrm{F} \\
\end{array}$} & \multirow[b]{2}{*}{$\%$} \\
\hline & & & $\mathrm{F}$ & $\%$ & $\mathrm{~F}$ & $\%$ & & \\
\hline $\begin{array}{l}\text { 27. Staff members are committed to programs } \\
\text { that enhance learning. }\end{array}$ & 2.78 & 1.22 & 128 & 51.4 & 39 & 15.7 & 82 & 32.9 \\
\hline $\begin{array}{l}\text { 28. Staff members collaboratively analyze } \\
\text { multiple sources of data to assess the } \\
\text { effectiveness of instructional practices. } \\
\text { 29. Staff members collaboratively analyze }\end{array}$ & 3 & 1.26 & 105 & 42.6 & 85 & 33.7 & 59 & 23.7 \\
\hline $\begin{array}{l}\text { student work to improve teaching and } \\
\text { learning. }\end{array}$ & 2.97 & 1.21 & 104 & 41.8 & 40 & 42.2 & 105 & 16.1 \\
\hline Total mean & 2.83 & 1.17 & 116.82 & 46.94 & 69.64 & 29.62 & 62.55 & 23.45 \\
\hline
\end{tabular}

\section{Shared Personal Practice}

The average rating, for each item 30 through 36 ranged from 2.79 to 3.36 and showed that, there were almost all disagreements ( except one professional learning community indicator- item 32) that elements of shared personal practice were evident in the university. In addition based on Hills levels of classification this dimension was found at the non-demonstration level in the implementation of PLC since the overall survey result for the positive response was $37.66 \%$. Item 32 which states that: staff members informally shared strategies and suggestions to improve student learning $(M=3.36, \mathrm{SD}=1.207)$ perceived to be implemented and received the maximum mean value. Whereas item 35 - Individuals and teams have the opportunity to apply learning and share the results of their practices $(\mathrm{M}=2.79, \mathrm{SD}=1.10)$ received minimum mean value.

Table 5-Results of professional learning community Survey Instrument - Shared Personal Practice.

\begin{tabular}{|c|c|c|c|c|c|c|c|c|}
\hline \multirow{2}{*}{ Item } & \multirow{2}{*}{$\mathrm{M}$} & \multirow{2}{*}{ SD } & \multicolumn{2}{|l|}{$\% \mathrm{D}$} & \multicolumn{2}{|l|}{$\% \mathrm{~A}$} & \multicolumn{2}{|l|}{$\%$ UD } \\
\hline & & & F & $\%$ & $\mathrm{~F}$ & $\%$ & $\mathrm{f}$ & $\%$ \\
\hline $\begin{array}{l}\text { 30. Opportunities exist for staff members to } \\
\text { observe peers and offer encouragement. }\end{array}$ & 2.8 & 1.19 & 120 & 48.2 & 85 & 34.1 & 44 & 17.7 \\
\hline $\begin{array}{l}\text { 31. Staff members provide feedback to peers } \\
\text { related to instructional practices. }\end{array}$ & 2.83 & 1.17 & 111 & 44.6 & 91 & 36.5 & 47 & 18.9 \\
\hline $\begin{array}{l}\text { 32. Staff members informally share ideas and } \\
\text { suggestions for improving student learning. } \\
\text { 33. Staff members collaboratively review }\end{array}$ & 3.36 & 1.20 & 76 & 30.5 & 146 & 58.6 & 27 & 10.8 \\
\hline $\begin{array}{l}\text { student work to share and improve } \\
\text { instructional practices. }\end{array}$ & 2.89 & 1.19 & 111 & 44.6 & 89 & 35.7 & 49 & 19.7 \\
\hline $\begin{array}{l}\text { 34. Opportunities exist for coaching and } \\
\text { mentoring. }\end{array}$ & 2.84 & 1.13 & 115 & 46.2 & 81 & 32.5 & 53 & 21.3 \\
\hline $\begin{array}{l}\text { 35. Individuals and teams have the opportunity } \\
\text { to apply learning and share the results of their } \\
\text { practices. }\end{array}$ & 2.79 & 1.10 & 113 & 45.4 & 75 & 30.1 & 61 & 24.5 \\
\hline $\begin{array}{l}\text { 36. Staff members regularly share student } \\
\text { work to guide overall university improvement. }\end{array}$ & 2.91 & 1.18 & 102 & 41 & 90 & 36.1 & 57 & 22.9 \\
\hline Total & 20.42 & 8.20 & 691 & 277.6 & 65 & 263.6 & 33 & 135.8 \\
\hline Mean & 2.92 & 1.17 & 98.71 & 39.66 & 93.8 & 37.66 & 48.29 & 19.40 \\
\hline
\end{tabular}

* $\mathrm{M}=$ mean, $\mathrm{SD}=$ Standard deviation, $\mathrm{D}=$ Disagree, $\mathrm{A}=$ Agree, $\mathrm{UD}=$ undecided

\section{Supportive Conditions - Relationships}

Means, for all items indicated that dimension of supportive conditions - relationships perceived to be unimplemented by the university $(M=2.86, S D=1.14)$ and this dimension was found at the non-demonstration level in the implementation of PLC, since the survey result showed only $42.77 \%$ respondents reflected the positive response . Item 40 - relationships among staff members support honest and respectful examination of data to enhance teaching and learning receives maximum mean value whereas, item 39 - staffs exhibit a sustained and unified effort to embed change into the culture of the university receives low mean value 
Table 6-Results of professional learning community Survey Supportive Conditions - Relationships

\begin{tabular}{|c|c|c|c|c|c|c|c|c|}
\hline \multirow{2}{*}{ Item } & \multirow{2}{*}{ M } & \multirow{2}{*}{ SD } & \multicolumn{2}{|l|}{$\% \mathrm{D}$} & \multicolumn{2}{|c|}{ \%ofA } & \multicolumn{2}{|c|}{ \%ofUD } \\
\hline & & & $\mathrm{F}$ & $\%$ & F & $\%$ & $\mathrm{f}$ & $\%$ \\
\hline $\begin{array}{l}\text { 37. A culture of trust and respect exists for } \\
\text { taking risks. }\end{array}$ & 2.85 & 1.133 & 106 & 42.57 & 77 & 30.92 & 66 & 26.5 \\
\hline $\begin{array}{l}\text { 38. Outstanding achievement is recognized } \\
\text { and celebrated regularly in our university. }\end{array}$ & 2.89 & 1.213 & 102 & 40.96 & 80 & 32.13 & 67 & 26.9 \\
\hline $\begin{array}{l}\text { 39. Staffs exhibit a sustained and unified effort } \\
\text { to embed change into the culture of the } \\
\text { university. }\end{array}$ & 2.84 & 1.078 & 105 & 42.17 & 73 & 29.32 & 71 & 28.5 \\
\hline $\begin{array}{l}\text { 40. Relationships among staff members } \\
\text { support honest and respectful examination of } \\
\text { data to enhance teaching and learning. }\end{array}$ & 2.89 & 1.154 & 113 & 45.38 & 82 & 32.93 & 54 & 21.7 \\
\hline Total & 11.47 & 4.578 & 426 & 171.08 & 312 & 125.3 & 258 & 103.6 \\
\hline Mean & 2.86 & 1.14 & 106.5 & 42.77 & 78 & 31.33 & 64.5 & 25.9 \\
\hline
\end{tabular}

* $\mathrm{M}=$ mean, $\mathrm{SD}=$ Standard deviation, $\mathrm{D}=$ Disagree, $\mathrm{A}=$ Agree, $\mathrm{UD}=$ undecided

Dimension 6: Supportive Conditions - Structures

The average rating for each of the items 41 through 48 ranged from 2.78 to 3.05 and showed that, there were general disagreements among the respondents that elements of supportive conditions related to structures were evident in the university $(M=2.92, S D=1.30)$. In addition, based on (Hill, 2007) levels of classification, since the survey result showed that, $35.99 \%$ respondents reflected positive responses this dimension was found at the nondemonstration stage in the implementation supportive condition- structure. Item 41 - the schedule provided opportunities for collective learning and collaboration" $(M=3.00, S D=1.14)$ received the maximum mean value; whereas item47 - communication systems promote a flow of information across the entire university community" $(M=2.78, S D=1.269)$ received the minimum mean value.

Table 7- Results of professional learning community Survey Supportive Conditions - Structures

\begin{tabular}{|c|c|c|c|c|c|c|c|c|}
\hline \multirow{2}{*}{ Item } & \multirow{2}{*}{ M } & \multirow{2}{*}{ SD } & \multicolumn{2}{|l|}{$\% \mathrm{D}$} & \multicolumn{2}{|l|}{$\%$ ofA } & \multicolumn{2}{|c|}{$\%$ ofUD } \\
\hline & & & $\mathrm{F}$ & $\%$ & $\mathrm{~F}$ & $\%$ & $\mathrm{f}$ & $\%$ \\
\hline 41. The university schedule promotes & 3.00 & 1.14 & & & & & 32 & 12.9 \\
\hline collective learning and shared practice. & & & 120 & 48.19 & 97 & 38.96 & & \\
\hline 42. Fiscal resources are available for & 2.97 & 1.28 & & & & & 53.0 & 21.3 \\
\hline professional development. & & & 104 & 41.77 & 92 & 36.95 & & \\
\hline 43. Appropriate technology and & 2.92 & 1.33 & & & & & & \\
\hline $\begin{array}{l}\text { instructional materials are available to } \\
\text { staff. }\end{array}$ & & & 120 & 48.2 & 97 & 38.89 & 32 & 12.9 \\
\hline $\begin{array}{l}\text { 44. Resource people provide expertise and } \\
\text { support for continuous learning. }\end{array}$ & 2.90 & 1.24 & 111 & 44.58 & 94 & 37.75 & 44 & 17.7 \\
\hline 45. The university facility is clean, & 2.84 & 1.38 & & & & & & \\
\hline attractive and inviting. & & & 119 & 47.79 & 91 & 36.55 & 39 & 15.7 \\
\hline 46. Communication systems promote a & 3.05 & 1.49 & & & & & & \\
\hline flow of information among staff members. & & & 98 & 39.36 & 78 & 31.33 & 51 & 20.5 \\
\hline 47. Communication systems promote a & 2.78 & 1.26 & & & & & & \\
\hline university community. & & & 122 & 49 & 80 & 32.13 & 47 & 18.9 \\
\hline 48. Data are organized and made available & 2.92 & 1.24 & & & & & & \\
\hline to provide easy access to staff members. & & & 107 & 42.97 & 88.00 & 35.34 & 54 & 21.7 \\
\hline Total & 23.3 & 10.41 & 901 & 361.86 & 717 & 287.90 & 352 & 141.5 \\
\hline Mean & 2.92 & 1.30 & 112.6 & 45.23 & 89.63 & 35.99 & 44.00 & 17.69 \\
\hline
\end{tabular}

* $\mathrm{M}=$ mean, $\mathrm{SD}=$ Standard deviation, $\mathrm{D}=$ Disagree, $\mathrm{A}=$ Agree, $\mathrm{UD}=$ undecided

Findings from the Open-Ended Responses

Research question 2 asked, "What are teachers' perceptions of professional learning communities?" different participants were viewed the term professional learning community differently, the most commonly reflected views were the one which says professional learning community is a collaborative and communicative process, where by different stake holders learn from each other to maintain conducive environment for the teaching learning process to take place. In addition, participants were viewed professional learning community as a process that involves a group of teachers who meet regularly as a team to identify essential and valued students learning, 
develop common formative assessments, analyze current levels of achievement, set achievement goals, share strategies, and create lessons to improve their teaching. The definition given by the above participants were best supported by the definition given by( Richardson, 2009; Desimone, 2011; Hunzicker, 2010) in that, these scholars viewed professional learning community as an effective professional development involving an active learning and teachers working collaboratively as a team to improve the quality of education.

In general, different participants were tried to define the term professional learning community differently. Though they were different in their views, their views can be summarized as defining Professional learning community as a collaborative process, a tool that fosters communication, a tool that enhances quality of education and a tool creates a conducive environment for students learning. Though the definition they gave to professional learning community touched the majority that the dimension of professional learning community is expected to touch, they failed to touch some of the important dimensions of professional learning community. For example, the definition given by the participants failed to include such important dimension of professional learning community as shared and supportive leader ship and shared values and vision.

The third research question states that "What do teachers perceive as enablers or challenges in initiating and developing an effective Professional learning community. Results obtained from the analyzed data indicates that, the majority of the respondents $40(68.9 \%)$ reported that teachers work load was one of the factor that affected the implementation professional learning community. Similarly, almost all of the respondents 50(86.2\%) were reported that lack of facilities and unavailability of organized offices are among the main factors that hampered the implementation of professional learning community in Ambo university. In their writings on an open ended question, lack of facilities/ resources such as lack of financial resources (financial resources are mentioned to be not yet decentralized in most of the colleges), lack of access to ICT, to journal and postal services are among the major factor that was mention by the respondents as a hindrance. They also incorporated in their writing, shortage of suitable and organized office use, in availability of free discussion rooms and unsuitability office structure/ shortage of office.

Notwithstanding with the above reality, almost all respondents were reported $45(77.5)$ that the majority of the staff member failed to understand the very concept and importance of professional learning community. This factor was reported in Fullan's writing when he says that, lack of understanding the importance of professional learning communities creates a challenge for its implementation by educators and administrators (Fullan, 2005). Reports obtained from an open ended question also explained that those who possess the understanding of the concept resist the change that will be made towards the professional learning community.

The data obtained from an open ended question revealed that leadership related factors such as, lack of leadership support, lack of continuous follow- up and poor evaluation and unavailability of clearly written guideline in relation to professional learning community practice in the university were reported to be the key factor that affects the implementation. In relation to this issue effective leadership plays a critical role in overcoming these obstacles for implementing and later sustaining Professional learning community (Dove \& Freely, 2011).

Other factors reported by the respondents related to teacher's culture to work together and lack of recognition and reward as barrier to the implementation of professional learning community was also identified.

The response obtained from an open ended questioner revealed that, background or culture of teachers to work with each other/to collaborate is another issue that was mentioned as a factor by the respondents. This is to say that, most teachers exhibited that poor culture to work together, poor culture to share experiences and lack of among trust with each other was a factor that affects the implementation of professional learning community. In addition, the response showed that the failurity of the university to provide reward and or acknowledgement is another factor.

Disarrangements of time and place among similar subject teaching teachers were other key factors. This is to say that time tables for those teachers especially who teaches similar subjects are not prepared in the ways that they can practice professional learning community. When one teacher teaches the other may be free of teaching and in this way their program found to mismatch to exercise professional learning community.

\section{Discussion}

The goal of this work was to examine professional learning communities: perceptions, challenges and possibilities. This study examined the six dimensions of professional learning communities as described by (Hord, 2004). Different universities around the world tried to practice professional learning communities but due various reasons the schools, principals, and teachers discontinued this practice (McLaughlin \& Metra, 2003; McLaughlin \& Talbert, 2006; Witmer \& Melnick, 2007). Some of the reason may include: lack of administrative support (Roberts \& Pruitt, 2009), strength of the learning communities, economic situations of students, types of learning experiences among teachers (Hargreaves, 2003; Reeves, 2000), school system resources and lack of financial support (Aguerrebere, 2008).

This study is regarded as being significant because Ambo University was encouraged to increase the 
development of professional learning communities. This study may assist teachers, principals, and other personnel in their considerations, implementations, and decisions to be to be teachers of the 21 st century and make dramatic improvements and changes in the current school practices to this model. It is through prepared and scholarly teachers that the necessary transformations will occur within the educational organizations. Through professional learning communities, educational teachers can exemplify the importance of teaching and learning as the focal point of education. Teachers can provide the necessary support and guidance to reform schools into schools that use professional learning communities (Hall \& Hord, 2006; Morrissey \& Cowan, 2004). Democratic leadership is necessary in order for this type of change to occur and sustain over time. Through appropriate leadership behaviors, attitudes, and actions, schools can develop into teach schools that support professional learning communities (McLaughlin \& Talbert, 2006). The vehicle for school change within schools begins and ends with the principals

\section{Conclusions}

An analysis of respondent mean scores for each of the forty 48 items for level of implementation revealed that all items except the four items had mean score less than 3.00. This indicates that out of the 48 professional learning community implementation indicator only $4(8.4 \%)$ indicators perceived by the teacher to be implemented by the university. The majority of indicators $42(87.5 \%)$ received mean less than 3.00 indicating that they were perceived to be unimplemented by the university. Furthermore, the percentage for the positive response for the six dimensions was found to be less than $44 \%$ indicating that the implementation for all dimensions of professional learning community was found at non-demonstration stage of PLC in the phases of development of a professional learning community.

In addition, when compared to the mean score $(M=3.0)$ from a hypothetical normal distribution, one-sample t-test results indicated the differences between the normal distribution and sample mean scores for all of the 48 indicator items were statistically significant at $p<.05$.

Supportive condition-structure and shared values and vision as dimension of professional learning community found to be ranked at the first level, whereas, shared and supportive leadership as a dimension of professional learning community appeared at the last stage.

Deferent participants were tried to define the term professional learning community differently. Though they were different in their views, their views can be summarized as defining Professional learning community as a collaborative process, a tool that fosters communication, a tool that enhances quality of education and a tool creates a conducive environment for students learning. Though the definition they gave to professional learning community touched the majority that the dimension of professional learning community is expected to touch, they failed to touch some of the important dimensions of professional learning community. For example, the definition given by the participants failed to include such important dimension of professional learning community as shared and supportive leader ship and shared values and vision.

In relation to the factors that can affect the implementation of professional learning community, survey response identified such a factor as : Teachers work load and the unavailability of time, unavailability of facility for the implementation of professional learning community, lack of understanding about professional learning community and resistance to change, lack of leadership support, lack of recognition and reward, the six question deals with disarrangements of time and place among similar subject teaching teachers were another key factors, in addition, factors such as, lack of awareness about the implementation of professional learning community, lack of time management skills, inability to plan, lack of communication skill, lack of skill based training, lack of commitment to change, rapidity of change, inadequate experience sharing among institution and work workload are among the key factors that can affect the implementation of professional learning community in Ambo University.

\section{Recommendations}

- The study shows the larger components of professional learning community indicators were failed to be implemented by the university (almost all the six dimensions) and the university found at nondemonstration stage of PLC. Hence, researchers recommended that the university needs to give due attention for the implementation of all the components of professional learning community.

- The definition given to PLC by the participants failed to include such important dimension of professional learning community as shared and supportive leader ship and shared values and vision. As the result, the university is expected to provide a kind of workshop for its staff so as to broaden their understanding level in relation to the concept.

- Deferent factors such as: teachers work load, lack of time, shortage of facility, lack of understanding about the concept of professional learning community and resistance to change were some of the key factors affecting the implementation of professional community. Hence, the university should work towards the minimization of these factors. 


\section{References}

Aryl, D., Jacobs, L.C., \& Razavieh, A. (2002). Introduction to research in education. (6th ed.). Belmont, CA: Wadsworth/Thomson Learning.

Barth, R.S. (2001). Learning by heart. San Francisco: Jossey-Bass.

Bolam, R., McMahon, A., Stoll, L., Thomas, S., Wallace, M., Hawkey, K., \& Greenwood, A. (2005). Creating and sustaining effective professional learning communities. DfES

Crowther, F., Ferguson, M., \& Hann, L. (2008). Developing teacher leaders (2nd ed.). Thousand Oaks, CA: Corwin Press.

Boyd, V. (1992). School context: Bridge or barrier to change. Austin, Texas: Southwest

Educational Development Laboratory. Retrieved on April 25, 2010, from www.sedl.org/change/school/leadership.html

DuFour, R., \& Eaker, R. (1998). Professional learning communities at work: Best practices for enhancing student achievement. Bloomington, IN: National Education Service.

DuFour, R., DuFour, R., Eaker, R., \& Karhanek, G. (2004). Whatever it takes: How professional learning communities respond when kids don't learn. Bloomington, IN: National Education Service.

DuFour, R., Eaker, R., \& DuFour, R. (2005). Recurring themes of professional learning communities and the assumptions they challenge. In R. DuFour, R. Eaker, \& R. DuFour . On common ground: The power of professional learning communities (pp.7-29)

DuFour, R., DuFour, R., Eaker, R., \& Many, T. (2006). Learning by doing: The handbook of professional learning communities at work. Bloomington, IN: Solution Tree.

Eaker, R., DuFour, R., \& Burnette, R. (2002). Getting started: Reculturing schools to become professional learning communities. Bloomington, IN: National Educational Service.

Elmore, R.F. (2007). School reform from the inside out: Policy, practice, and performance (3rd ed.). Cambridge, MA: Harvard Educational Press.

Fullan, M. (1991). The change leader. Center for Development and Learning. Retrieved on April 28, 2010, from http: www.cdl.org/resource-library/articles/change ldr.php.

Fullan, M. (2005). Leadership \& sustainability: System thinkers in action. Thousand Oaks, CA: Corwin Press.

Fullan, M. (2007). Change the terms for teacher learning. Journal of Staff Development, 28(3), 35-36.

Fuller, E., \& Young, M.D. (2009, Summer). Texas high school project leadership initiative issue brief 1: Tenure and retention of newly hired principals in Texas.

Gehrke, N. (1991). Developing teachers' leadership skills (ERIC Document Reproduction Service No. ED330691).

Graham, P. (2007, January, 22). The role of conversation, contention, and commitment in a professional learning community. Connexions. Retrieved, February 11, 2009, from http://cnx.org/content/m14270/latest

Hall, G.E., \& Hord, S.M. (2006). Implementing change: Patterns, principles, and potholes. Boston: Pearson Education.

Hargreaves, A. (2003). Teaching in the knowledge society: Education in the age of insecurity. New York: Teachers College Press.

Hord, S.M. (1996). School professional staff as learning community [Questionnaire]. Austin, TX: Southwest Educational Development Laboratory.

Hord, S.M. (1997). Professional learning communities: Communities of continuous inquiry and improvement. Austin, TX: Southwest Educational Development Laboratory.

Hord, S.M. (Ed.). (2004). Learning together, leading together: Changing schools through professional communities. New York: Teachers College Press.

Hord, S.M. (2008). Evolution of the professional learning community. Journal of Staff Development, 29(3), 1013.

Hord, S.M., \& Hirsh, S.A. (2008). Making a promise a reality. In A.M. Blankstein, P.D.

Houston, \& R.W. Cole (Eds.), Sustaining professional learning communities (pp 23-40).

Thousand Oaks, CA: Corwin Press.

Hord, S.M., Meehan, M.L., Orletsky, S., \& Sattes, B. (1999). Assessing a school staff as a community of professional learners. Issues...about change, 7(1), 1-10. (ERIC Document Reproduction Service No. ED439490).

Hord, S.M., \& Sommers, W.A. (2008). Leading professional learning communities: Voices from research and practice. Thousand Oaks, CA: Corwin Press.

Hrebeniuk, M. (n.d.). The quality and characteristics of a good leader. Ezine Articles. Retrieved April 18, 2010, from http;//ezinearticles.com/?The-Quality-And-Characteristics-Of-AGood-Leader\&id=4295642

Kruse, S., Louis, K.S., \& Bryk, A. (1994). Building professional community in schools. Issues

Little, J.W. (1988). Assessing the prospects for teacher leadership. In A. Lieberman (Ed.), Building a professional culture in schools (pp. 78-106). New York: Teachers College press

Little, J.W. (2000). Assessing the prospects for teacher leadership. In M. Fullan (Ed.), The Jossey-Bass reader on 
educational leader (1st ed., pp. 348-365). San Francisco: Jossey-Bass

Little, J.W., \& McLaughlin, M.W. (Eds.). (1993). Teachers' work: Individuals, colleagues, and contexts. New York: Teachers College Press.

Martin-Kniep, G.O. (2008). Communities that learn, lead, and last: Building and sustaining educational expertise. San Francisco: John Wiley \& Sons.

McLaughlin, M.W., \& Mitra, D. (2003). The cycle of inquiry as the engine of school reform: Lessons from the Bay Area School Reform Collaborative. Sanford, CA: Center for Research on the Context of Teaching, Sanford University.

McLaughlin, M.W., \& Talbert, J.E. (2006). Building school-based teacher learning communities: Professional strategies to improve student learning. New York: Teachers College Press.

Meehan, M.L., Orletsky, S.R., \& Sattes, B. (1997). Field test of an instrument measuring the concept of professional learning communities in schools. Charleston, WV: Appalachian Educational Laboratory. (ERIC Document Reproduction No. ED433358

Melnick, S.A., \& Schubert, M.B. (1997, March). Curriculum integration: Essential elements or success. Chicago: American Educational Research Association. (ERIC Document Reproduction Service No. ED41330) Midcontinent Research for Education and

Reichstetter, R. (2008). Wake County Public School System professional learning communities: 2007-08 implementation status. (Evaluation \& Report No. 08.06). Retrieved March 9, 2008, from http://www.wcpss.net/evaluations-research

Reichstetter, R., \& Baenen, N. (2007). Professional learning communities (PLC) implementation: WCPSS 200607 baseline survey results. (Evaluation \& Report No. 06.19). Retrieved March 9, 2008, from http://www.wcpss.net/evaluations-research

Roberts, S.M., \& Pruitt, E.Z. (2003). Professional learning communities: Collaboration and strategies for professional development. Thousand Oaks, CA: Corwin Press.

Schmoker, M. (2006). Results now: How to achieve unprecedented improvements in teaching and learning. Alexandria, VA: Association for Supervision and Curriculum Development

Senge, S.M. (1990). The fifth discipline: The art and practice of the learning organization. New York: Doubleday.

Schmoker, M. (2005). No turning back: The ironclad case for professional learning communities. In R. DuFour, R. Eaker, \& R. DuFour (Eds.), On common ground: The power of professional learning communities (pp. 135-153). Bloomington, IN: Solution

Vetter, J.B. (2008). A leadership team approach to sustaining social and emotional learning. In A.M. Blankstein, P.D. Houston, \& R.W. Cole (Eds.), Sustaining professional Learning communities (pp. 97-120). Thousand Oaks, CA: Corwin Press.

Witmer, J.T., \& Melnick, S.A. (2007). Team-based professional development 